\title{
CYLD tumour supressor regulates ciligenesis
}

\author{
T Eguether $^{r^{*}}$, BM Bonnet ${ }^{2}$, EM Ermolaeva ${ }^{2}$, PM Pasparakis ${ }^{2}$, CG Courtois $^{3}$, TAM Tassin ${ }^{1}$ \\ From First International Cilia in Development and Disease Scientific Conference (2012) \\ London, UK. 16-18 May 2012
}

The tumor suppressor CYLD gene encodes a deubiquitinating enzyme that removes lys-63-linked ubiquitin chains. CYLD regulates, by its catalytic domain, NF-kB, c-Jun kinase and $\mathrm{Wnt} / \beta$-catenin signalling pathways. When mutated in its catalytic domain CYLD cause skin appendages tumors as in familial cylindromatosis. We have found CYLD as a partner of the centrosomal protein CAP350 in immunoprecipitation experiments followed by mass spectrometry. CAP350 was shown to play a role in microtubule stabilization (Hoppeler-Leber et al, 2007). Here, we show that CYLD localizes to the centrosome in cells and is enriched in purified centrosomes. To understand the functional interaction between CYLD and CAP350, we studied mice carrying deletion of part of the deubiquitinase domain and mimicking the human pathology. These homozygous mice cyld (del17/del17) die perinatally due to respiratory dysfunction and exhibit immature lung phenotype. To test if CYLD is involved in ciliogenesis, we studied the presence of motile cilia in the trachea. Cyld (del17/del17) embryo tracheas exhibit a decreased number of ciliated cells compared to wild type ones of the same litter. In addition, these ciliated cells have fewer and shorter cilia. Similar results were obtained on ependymal cell culture. Transmission electron micrographs demonstrate that most of the basal bodies fail to anchor to the plasma membrane. We demonstrate that in MEFs derived from cyld (del17/del17) embryo, CYLD and CAP350 do not longer interact in contrast to MEFs derived from wild type embryo. In addition, these mutant MEFs exhibit primary cilia growth defect compared to MEFs derived from wild type mice.

\section{Author details}

${ }^{1}$ Institut Curie INSERM U759, France. ${ }^{2}$ Cologne University, Germany.

${ }^{3}$ INSERM, France.

Published: 16 November 2012

* Correspondence: thibaut.eguether@curie.fr

${ }^{1}$ Institut Curie INSERM U759, France

Full list of author information is available at the end of the article
doi:10.1186/2046-2530-1-S1-P66

Cite this article as: Eguether et al: CYLD tumour supressor regulates

ciligenesis. Cilia 2012 1(Suppl 1):P66.
Submit your next manuscript to BioMed Central and take full advantage of:

- Convenient online submission

- Thorough peer review

- No space constraints or color figure charges

- Immediate publication on acceptance

- Inclusion in PubMed, CAS, Scopus and Google Scholar

- Research which is freely available for redistribution

Submit your manuscript at www.biomedcentral.com/submit

\section{() Biomed Central}

\section{Ciomed Central}

C 2012 Eguether et al; licensee BioMed Central Ltd. This is an Open Access article distributed under the terms of the Creative Commons Attribution License (http://creativecommons.org/licenses/by/2.0), which permits unrestricted use, distribution, and reproduction in any medium, provided the original work is properly cited. 